\title{
The Critical Role of Art: Adorno between Utopia and Dystopia
}

Paolo A. Bolaños

\begin{abstract}
In the drama of conscious existence, it is not theory and practice that encounter each other, but enigma and transparency, phenomenon and insight. If enlightenment does occur, it does so no through the establishment of a dictatorship of lucidity but as the dramatic selfillumination of existence. - Peter Sloterdijk ${ }^{1}$
\end{abstract}

\section{Introduction}

$\mathrm{R}$ eading or hearing about Theodor Adorno's ideas always results in quibbles. He strikes many as a naïve philosopher because of his reversal of concept and object; some see him as an anarchist because of his relentless critique of rationality; while to others he simply does not make sense, and especially a critique of society based on negative dialectics simply does not make sense to many! These points, however, are precisely some of the key elements of his thought; without a deeper apprehension of these main themes, it would be impossible to arrive at a level-headed appraisal of his philosophy.

Adorno's philosophy revolves around the idea that the history of rationality has relapsed into barbarism; that irrationality itself inheres in rationality. In Minima Moralia, he writes, "Our perspective of life has passed into an ideology which conceals the fact that there is life no longer." 2 What modernity or Enlightenment promises are the liberation of men from fear and the establishment of their sovereignty through the disenchantment of the world and the dissolution of myths; ${ }^{3}$ this is how we are seduced by Enlightenment. It was through the triumph of knowledge over our caprices that liberation was supposedly achieved. For Adorno, however, this promise of liberation is but another caprice, and a subtle one. The promise hides behind the façade of rationality — of enlightened knowledge-but its real nature is one that contradicts its façade. "There is to be no mystery" in

${ }^{1}$ Thinker on the Stage: Nietzsche's Materialism, trans. by Jamie Owen Daniel (Minneapolis: University of Minnesota Press, 1989), xxv-xxvi.

2 Theodor Adorno, Minima Moralia: Reflections on a Damaged Life, trans. by E. F. N. Jephcott (London: Verso, 2005), 15.

3 Cf. Theodor Adorno and Max Horkheimer, Dialectic of Enligbtenment, trans. by John Cumming (London: Verso, 1997), 3. 


\section{THE CRITICAL ROLE OF ART}

knowledge, "which means, too, no wish to reveal mystery."4 Society's blind and blanket acceptance of the promise of Enlightenment distorts the faculty of perception. Enlightenment promises the "good life" while in fact, as a veil, masks the very possibility of life.

Adorno's seemingly bleak view of a reified society might be misinterpreted as sheer pessimism. However, I will argue in this paper that through Adorno's "aesthetics of redemption," it is possible to conceive of art as a medium of creating a dimension of imagined freedom. An artwork can present itself as an opposition to the present and thereby open up the present to the future. The future is a realm of hope; but art does not guarantee that the future will be better than the present. The most that art can do for us is to aid us in our battle against total reification and to arouse a sort of nostalgia without content. This is the most that art can do for us since even art can be commodified. I agree with Nicholas H. Smith when he writes that critical theorists "have at least one thing in common: hope for a better world." 5 But for Adorno hope will always have to be negative, for it will not allow itself to be justified in terms of naïve conceptions of humanism, teleology, and divine providence. Such notion of social hope is perhaps close to what Smith calls "ungroundable hope." 6 Our conceptualizations of utopias will always fall short of capturing what is hoped for.

The paper is guided by one crucial question: is art for the sake of entertainment, or is it something more than mere entertainment? What I wish to present is that art is more than entertainment; Adorno's aesthetics of redemption highlights the critical role of art in society. Far from being a means of reconciling the internal contradictions of society, art participates in the dialectical dynamism of society and culture; it realizes itself as a product of this dialectic and, as a result, mobilizes itself a counter-culture of well accepted culture or ideology. Yet, art remains negative-it is only through negativity that it escapes the naïve optimism of knowledge and the culture industry. Art in this sense becomes the nemesis of positive knowledge taken for granted by the culture industry as its patron. Inasmuch as art is a critique of ideology, it becomes a revelation of the real status of society as dystopia. Nevertheless, Adorno is not quick to perform a leap of faith, that is, a naïve conceptualization of a utopia; because his philosophy remains negative, Adorno remains between utopia and dystopia.

\section{Aesthetics in a Damaged Culture}

Adorno's relation to and conception of aesthetics is peculiar. As an artist, he was trained as a classical composer, well versed in the tradition and technicalities of modern music. Meanwhile, Adorno could also be regarded as a supporter of the avant-garde. His conception of aesthetics is by no means

${ }^{4}$ Ibid., 5.

5 See Nicholas H. Smith, "Hope and Critical Theory," in Critical Horizons, 6:1 (2005), 45-61.

${ }^{6}$ See Ibid. 
naïve, and he writes that "the qualities which the word 'culture' acquired [following the rise of the bourgeoisie to political power] allowed the rising class to achieve its goals in economy and administration." 7 In this sense, industry became, as it were parasitic to culture, and in particular to art. Adorno tells us that "no half-way sensitive person can overcome the discomfort conditioned by his consciousness of a culture which is indeed administered." 8 And that the ultimate consequence of this is that "culture suffers damage when it is planned and administered ...."9 Moreover, not only that what is "cultural is that which is removed from the naked necessity of life," 10 culture has pathologically developed a fetish character, for instance in the case of music. Adorno writes: The consciousness of the mass listeners is adequate to fetishized music . ... But if someone tried to 'verify' the fetish character of music by investigating the reactions of the listeners .... The unconscious reactions of the listeners are so heavily veiled and their conscious assessment is so exclusively oriented to the dominant fetish categories that every answer one receives conforms in advance to the surface of that music business .... ${ }^{11}$

This is how Adorno would describe the conformism that the culture industry engrafts into the consumers of music. The fetish character of contemporary music is further described as "a regression in listening," not as a reversion to a previous state, but as an arrest "at an infantile stage," 12 which means that contemporary music has been rendered stagnant by the mechanism of business - the so called "music industry" or "show business." Music, as in any kind of art, is manufactured for the consumption of the many. It is in this sense the culture is reduced to mere entertainment. We read in Philosophy of Modern Music.

... the transition to the calculated manufacture of music as a mass-produced article has taken longer than has the analogous process in literature or the fine arts. The nonconceptual and non-objective element in music which, since Schopenhauer, has accounted for music's appeal to irrational philosophy, has served only to harden it against the market-place mentality. Not until the era of sound film, the radio, and the singing commercial began was its very irrationality expropriated by the logic of the business world. ${ }^{13}$

7 Theodor Adorno, "Theory of Pseudo-Culture," quoted in Alex Thomson, Adorno: A Guide for the Perplexed (London: Continuum, 2006), 77.

${ }^{8}$ Theodor Adorno, The Culture Industry (London: Routledge, 1991), 108.

${ }^{9}$ Ibid.

${ }^{10}$ Ibid., 109

${ }^{11}$ Ibid., 45.

12 Ibid., 46.

13 Theodor Adorno, Philosopby of Modern Music, trans. by Anne G. Mitchell and Wesley V. Blomster (New York: Continuum, 2003). 5. 


\section{THE CRITICAL ROLE OF ART}

This, for Adorno, is a consequence of the development of the monopolistic means of distributing cultural goods; the culture industry has established itself as a totality, and "it also gained power over whatever did not aesthetically conform."14 This is the new, and twisted, conformism that Adorno speaks about, a deviation from the rules of music and the submission to the logic of industry. This new conformism results in regressive listening:

Regressive listening is tied to production by the machinery of distribution, and particularly by advertising . . . nothing is left for the consciousness but to capitulate before the superior power of the advertised stuff and purchase spiritual peace by making the imposed goods literally its own thing. ${ }^{15}$

The overwhelming power of symbols and imagery through advertising is a subtle manifestation of domination. The commercialization of art, in this case music, is but part of the totalizing tendency of the culture industry, for "culture now impresses the same stamp on everything." 16 In the specific case of art, its commercialization produces an artificial 'need' in the consumers and thereby relegating the status of art to mere entertainment. The culture industry not only undermines the autonomy of art but extirpates from it its internal logic. The culture industry imposes on the artwork a logic external to it, that is, of "standardization" and "rationalization."17 An artwork is standardized according to what is familiar with the consumers, a familiarity which has been pre-determined by the culture industry itself; the predominance of Hollywood films is typical of this. The process of distribution should also be made rational-standardization of course inheres within this scaffolding- "the technique of the culture industry is, from the beginning, one of distribution and mechanical reproduction ...."18 This is seen in the chronological production of a movie (Da Vinci Code) - from its very conception to its distribution through different types of media, the cinema and later on the consumption of DVDs. An integral element of this scaffolding is of course "media-hype," that is, the mobilization of a synergy of various media (the hocus-pocuses range from flyers, billboards, TV, radio, the internet, down to mobile ringtones) and the production of products which are intended to promote a film (ranging from T-shirts, caps, down to McDonald's soda cups with Superman or Star Wars characters printed on them!). The proliferation of family TV programs such as Idol, for example, shows how the culture industry separates the form and content of art (singing/music) from the artist and his/her work. In a singing competition like Idol musical talent comes secondary to appearance and the supposed marketability of the contestant; at the end of the day, a contestant is gauged not by talent but by the size of his/her fan-base. The ideology of the culture industry, Adorno writes,

\footnotetext{
${ }^{14}$ Ibid., 6.

15 Adorno, Culture Industry, 47-48.

16 Adorno and Horkheimer, Dialectic of Enlightenment, 120.

${ }^{17}$ See Adorno, The Culture Industry, 100.

${ }^{18}$ Ibid., 101.
} 
. . . makes use of the star system, borrowed from individualistic methods of operation and content, the more diligently and successfully the culture industry propagates supposedly great personalities and operates with heart-throbs. ${ }^{19}$

This form of domination, in the eyes of Adorno, is however peculiar. On the one hand, he conceives of the culture industry as a totalizing mechanism of control through the technological production and repetition of needs, where the "technological rationale is the rationale of domination itself." 20 On the other hand, Adorno does not think that consumers are simply duped by the culture industry. "The concept of order," he writes, which the culture industry "hammers into human beings are always those of the status quo," 21 and that "if it guarantees them even the most fleeting gratification they desire a deception which is nonetheless transparent to them." 22 Conformism is the peculiarity of this form of domination-it induces a pathological instinct (and in this sense it is successful in conquering nature by playing on our instincts!) on the part of the consumers to desire deception. As an ideology, the culture industry becomes a new form of religion or pop-religion; it is legitimated by "the spiritual constitution of the masses" 23 and its promise of providing "standards of orientation" 24 to organize a chaotic world.

\section{The Critical Role of Art}

Art itself is ambivalent. While, on the one hand, art has always been vulnerable to the exploitation of the culture industry, on the other hand, Adorno still thinks that art plays a very important role in the prognosis of the "dysfunctional" nature of a purely functional world. I have glossed Adorno's notion of the culture industry above as that which induces and maintains a pathological conformism. "The power of the culture industry's ideology is such that conformity has replaced consciousness." 25 This is perhaps the greatest danger that the culture industry poses on us. It is not so much direct physical harm that Adorno fears as it is with the stupefaction of the masses, that is, the harm that results in the diminishment of critical incredulity.

The critical role of art, as opposed to mere entertainment, is based on Adorno's claim that art has a truth-content. For Adorno, art, inasmuch as art is a product of society, has a dialectical character. The truth-content of a work of art "inheres in the determinate negation of untruth." 26 Indeed, art must be

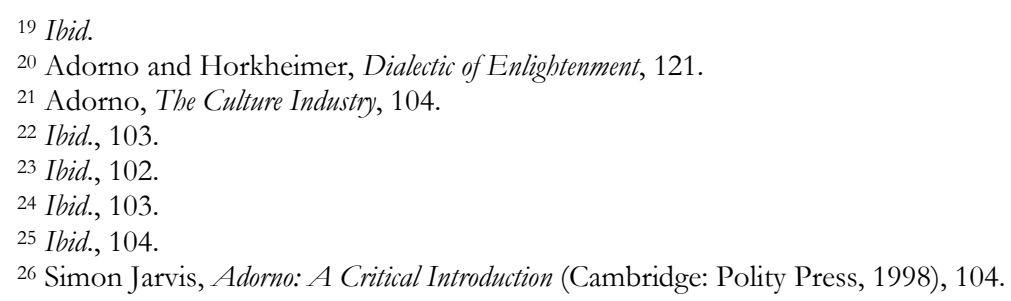




\section{THE CRITICAL ROLE OF ART}

consistent with Adorno's negative dialectics. It is in this sense that art is a counter-pressure to society - a society obsessed with identity. Adorno maintains that art has the character of seeking "to aid the nonidentical, which in reality is repressed by reality's compulsion to identity." 27 Adorno further argues that art must confront the dialectic of enlightenment "with the aesthetic conception of anti-art," and the source of its "power of resistance is that a realized materialism would be at the same time be . . the abolition of the domination of material interest." 28

As pointed out at the outset, Adorno provides enough room for social hope. He writes in Aesthetic Theory:

At the center of contemporary antinomies is that art must be and wants to be utopia, and the more utopia is blocked by the real functional order, the more this is true; yet at the same time, art may not be utopia in order not to betray it by providing semblance and consolation. If the utopia of art were fulfilled, it would be arts temporal end (emphasis mine). ${ }^{29}$

In this instance, Adorno deploys the critical role of art. Art creates a dimension of imagined freedom. Such freedom is sensitive to the negative position of critique toward both nature and non-nature. The dimension of utopia that art creates is not a positive one, in fact, it is a moment when a "lack" is realized. In this sense, art is negative; as a critique of a society damaged by reification, art amounts to the exposure of the "untruthfulness" of the whole. It should remain negative so it would not betray its function as a constant reminder that reason's attempt to ground and conquer nature through reason is hubris. Adorno also notes:

Artworks are afterimages of empirical life insofar as they help the latter to what is denied them outside their own sphere and thereby free it from that to which they are condemned by reified external experience..$^{30}$

The role of art, therefore, is a reminder of a lack, that the present society lacks something. This realization of a lack is the precondition of social critique. An artwork can present itself as an opposition to the present and, thus, opens up the present to the future. The future is the realm of hope. The future, however, is perhaps more problematic for Adorno; for the space that hope creates does not guarantee that the future will be better than the present. The most that art can do for us is to aid us in our battle against total reification

27 Theodor Adorno, Aesthetic Theory, trans. by Robert Hullot-Kentor (London: Continuum, 2004), 5.

${ }^{28}$ Ibid., 37.

${ }^{29}$ Ibid., 41.

${ }^{30}$ Ibid., 5. 
and to arouse a sort of nostalgia without content. This is the most that art can do for us for even art can be commodified. In this day and age, art is indeed a commodity! "The artwork," Adorno writes, "is semblance not only as the antithesis to existence but also in its own terms." 31

For Adorno, there should be a concurrence between philosophy and art. It is the task of art to remind philosophy of dystopia and philosophy's own blunders; it is the task of philosophy not guard itself from reading false utopias out of art: philosophy should be a demonstration of the way in which art opens us to the "new" by being its constant nemesis, that is, a critique of the past and the present. Hence, art does not promise us a utopia, for our conceptualizations of utopias will always fall short of capturing what is hoped for. The glimmer of hope which art evinces will always, and must be, negative, for it will not allow itself to be justified in terms of naïve conceptions of humanism, teleology, and divine providence.

Adorno evokes his strongest plea for social hope in Minima Moralia: "The only philosophy which can be responsibly practiced in face of despair is the attempt to contemplate all things as they would present themselves from the standpoint of redemption." 32 Redemption, however, should not fall back to the fundamental fiction of identity thinking - it should be more modest this time. And since it is undignified to recourse to Reason or divine providence, we have to realize that the present state of society is our own making. Praying for our future will not help us, our openness towards it might.

Faculty of Arts and Letters, University of Santo Tomas, Philippines Department of Philosophy, Macquarie University, Australia

\section{References}

Adorno, Theodor and Max Horkheimer, Dialectic of Enlightenment, trans. by John Cumming (London: Verso, 1997).

Adorno, Theodor, Aesthetic Theory, trans. by Robert Hullot-Kentor (London: Continuum, 2004). Minima Moralia: Reflections on a Damaged Life, trans. by E. F. N. Jephcott (London: Verso, 2005). Philosophy of Modern Music, trans. by Anne G. Mitchell and Wesley

V. Blomster (New York: Continuum, 2003).

Jarvis, Simon, Adorno: A Critical Introduction (Cambridge: Polity Press, 1998).

Sloterdijk, Peter, Thinker on the Stage: Nietzsche's Materialism, trans. by Jamie Owen Daniel (Minneapolis: University of Minnesota Press, 1989).

Smith, Nicholas H., "Hope and Critical Theory," in Critical Horizons, 6:1 (2005), 45-61.

Thomson, Alex, Adorno: A Guide for the Perplexed (London: Continuum, 2006).

${ }^{31}$ Ibid., 138.

32 Adorno, Minima Moralia, 247. 